\title{
MORPHOLOGICAL AND MOLECULAR CHARACTERISTICS OF Panax sp. (Araliaceae) FROM PHU XAI LAI LENG MOUNTAIN, NGHE AN PROVINCE, VIETNAM
}

\author{
Phan Ke Long ${ }^{1}$, Tran Thi Viet Thanh ${ }^{1}$, Nguyen Thien Tao ${ }^{1}$, \\ Phan Ke Loc ${ }^{2}$, Nguyen Tu Lenh ${ }^{3}$, Nguyen Tien Lam³, Dang Xuan Minh \\ ${ }^{1}$ Vietnam National Museum of Nature, VAST, *pklong@ vnmn.vast.vn \\ ${ }^{2}$ Hanoi University of Science, Vietnam National University \\ ${ }^{3}$ Department of Agriculture and Rural Development, Nghe An Province
}

\begin{abstract}
Seven sterile and young specimens of Panax sp. were collected in Phu Xai Lai Leng silicat mountain, the highest mountain peak in central Vietnam. Morphologically, they resemble $P$. stipuleanatus and $P$. bipinnatifidus. However, they have stipules and leaflets that are not bipinnatifid. The ITS-DNA sequences of Panax sp. from Phu Xai Lai Leng are identical and exhibit a close relationship with P. stipuleanatus from Tam Duong district, Lai Chau province with strong bootstrap support (98\%). Noticeably, these two taxa are different by 2 nucleotides. A collection of standard specimens including inflorescence, infructescence, flowers and ripe fruits of Panax from Phu Xai Lai Leng is needed to determine its taxonomic status.
\end{abstract}

Keywords: Panax, ITS-rDNA, morphology, Phu Xai Lai Leng silicate mountain.

\section{INTRODUCTION}

In the world, the genus Panax comprises 6 species distributing in North America and East Asia [5, 6]. The Plant List included 12 valid species of Panax [8]. In China, 6-7 species Panax are recognized [9]. In Vietnam, this genus consists of three known [1, 2, 3, 4], namely, $P$. bipinnatifidus Seem., $P$. stipuleanatus and $P$. vietnamensis. The occurrence of three other species, namely, $P$. pseudoginseng [9], $P$. zingiberensis and $P$. notoginseng [9] are doubtful and should be confirmed by voucher specimens.

During a recent survey of Panax plants on the north-eastern slope of Phu Xai Lai Leng mountain, western Nghe An Biosphere Reserve, north central Vietnam, we collected 7 specimens belonging to this genus with leaves similar to those of $P$. pseudoginseng, $P$. bipinnatifidus and $P$. stipuleanatus. In this paper, we provide morphological and molecular characteristics of the collected specimens.

\section{MATERIALS AND METHODS}

\section{Morphological characteristics}

Seven Panax specimens, mostly sterile and young (except specimen NTL 101 which is adult) were collected in Phu Xai Lai Leng Mountain (table 1). Morphological characteristics were described from the fresh specimens in the field and laboratory. Photographs were taken using a "Canon EOS 200" camera with "Canon" and "Cosina" lenses of various focal distances. Voucher herbarium specimens were deposited in the herbaria of the Vietnam National Museum of Nature (VNMN) and of the Hanoi University of Science (HNU).

\section{Molecular characteristics}

Total DNA was extracted from dried leaves using the DNeasy Plant Minikit (Qiagen, Singapore). The ITS-rDNA regions were amplified using the forward primer PaITSF 5'CAC TGA ACC TTA TCA TTT AG AG -3' and the reverse primer PaITSR 5'-CTT ATT GAT ATG CTT AAA CTC AG-3' was designed based on the ITS sequence of the genus Panax obtained from GenBank. After purification, DNA fragments were sequenced with a BigDye Terminator Cycle Sequencing Ready Reaction kit (PE Applied Biosystems, Foster City, CA, USA) and run on an ABI PRISM 3100 Genetic Analyzer (PE Applied Biosystems). All sequences were submitted to Genbank with the accession number as follow: 
Phan Ke Long et al.
KP091694
(NTL101)
KP091695
(NTL106), KP091698 (NTL102), KP091699
(NTL104), KP091696
(NTL105),
KP091697
(NTL103), KP091700 (NTL107).

Table 1. Panax sp. specimens collected in Phu Xai Lai Leng mountain, western Nghe An province

\begin{tabular}{cccccl}
\hline $\mathrm{N}^{\mathrm{o}}$ & Code & Latitude, N & Longitude, E & $\begin{array}{c}\text { Altitude } \\
\text { a.s.l. }\end{array}$ & \multicolumn{1}{c}{ Habit } \\
\hline 1 & NTL 101 & $19^{\circ} 13^{\prime} 16^{\prime \prime}$ & $104^{\circ} 11^{\prime} 59^{\prime \prime}$ & $1599 \mathrm{~m}$ & $\begin{array}{l}\text { Adult plant, 20-30 cm tall with } \\
\text { fallen inflorescence }\end{array}$ \\
2 & NTL 102 & $19^{\circ} 13^{\prime} 23^{\prime \prime}$ & $104^{\circ} 11^{\prime} 57^{\prime \prime}$ & $1595 \mathrm{~m}$ & Young plant, 20-30 cm tall \\
3 & NTL 103 & $19^{\circ} 13^{\prime} 22^{\prime \prime}$ & $104^{\circ} 11^{\prime} 58^{\prime \prime}$ & $1599 \mathrm{~m}$ & Young plant, 20-25 cm tall \\
4 & NTL 104 & $19^{\circ} 13^{\prime} 23^{\prime \prime}$ & $104^{\circ} 11^{\prime} 57^{\prime \prime}$ & $1597 \mathrm{~m}$ & Young plant, 20-25 cm tall \\
5 & NTL 105 & $19^{\circ} 13^{\prime} 18^{\prime \prime}$ & $104^{\circ} 11^{\prime} 59^{\prime \prime}$ & $1627 \mathrm{~m}$ & Young plant, 20-25 cm tall \\
6 & NTL 106 & $19^{\circ} 13^{\prime} 18^{\prime \prime}$ & $104^{\circ} 11^{\prime} 59^{\prime \prime}$ & $1627 \mathrm{~m}$ & Young plant, 20 cm tall \\
7 & NTL 107 & $19^{\circ} 13^{\prime} 18^{\prime \prime}$ & $104^{\circ} 11^{\prime} 59^{\prime \prime}$ & $1627 \mathrm{~m}$ & Young plant, 17 cm tall \\
\hline
\end{tabular}

Sequences of 7 Panax specimens from Phu Xai Lai Leng mountain were aligned using Clustal X 1.64 [9] with sequences of Panax spp., according to Phan et al. [4].

Equally weighted maximum parsimony (MP) analyses were performed using PAUP* (4.0 beta version) [7]. A heuristic search procedure was used with the following settings: ten replicates of random taxon addition, treebisection reconnection branch swapping, multiple trees retained, no steepest descent, and accelerated transformation. Gaps were treated as missing data. Bootstrap analysis was carried out with 100 replicates.

\section{RESULTS AND DISCUSSION}

\section{Morphological characteristics}

According to the leaf morphology, the 7 specimens of Panax collected from Phu Xai Lai Leng can be identified as two groups: group PXLL-1 with divided leaflets and group PXLL2 with undivided leaflets.

Groups of specimens PXLL-1: Leaflets from slightly lobed to pinnatifid (specimens NTL 101, NTL $102 \&$ NTL 103) (fig. 1).

Herb, perennial, 0.2-0.3 $\mathrm{m}$ tall (without inflorescence/infructescence). Rootstock moniliform-mounded, usually horizontal, resembling that of species of Zingiber. All plant parts glabrous except for scattered setulose hairs on veins of adaxial leaf surface, very rare on abaxial leaf surface; trichomes $1.5-2 \mathrm{~mm}$ long. Leaves of adult plants usually $3-4$, verticillate at apex of stem, palmately compound; petioles 3-9 $\mathrm{cm}$ long, base with stipules or stipule-like appendages, deltoid-cuspidate, less than $2 \mathrm{~mm}$ long. Leaflets $5(-7)$, membranous, from slightly lobed to pinnatifid, margin serrulate; central leaflet largest, up to $17 \times 6 \mathrm{~cm}$, elliptic, rarely oblanceolate in outline, acute at base, cuspidate or long cuspidate, rarely acuminate at apex with leaf blade 2.4-2.8 as long as wide, petiolules $0.8-1.5 \mathrm{~cm}$ long, at base sometimes with some trichomes similar to the ones on nerves of leaf blades; lateral leaflets smaller; the lowermost pair of leaflets smallest, rhombic-ovate or obovate, asymmetric, base broadly cuneate or subrounded, margin serrate. Inflorescence and infructescence, flowers and fruits unknown.

The specimens differ from Panax stipuleanatus by the smaller vegetative parts, not up to 0.4-0.6 m, petiole base with stipules or stipule-like appendages and leaflets not 2pinnatifid. Description of rhizome of this species made by Xiang \& Lowry II (2007) [9] as fusiform was inaccurate, but rather "thick, elongate, finally zigzag" as observed in the isotype specimen Feng 13694 (KUN 0448506!).

The specimens differ from Panax bipinnatifidus by the leaflets which are not bipinnatifid, adaxially sparsely setose, and base of petiole with stipules or stipule-like appendages.

Groups of specimens PXLL-2: Leaflets undivided (NTL 104, NTL 105, NTL 106 \& NTL 107). All specimens are young plants (fig. 1) 


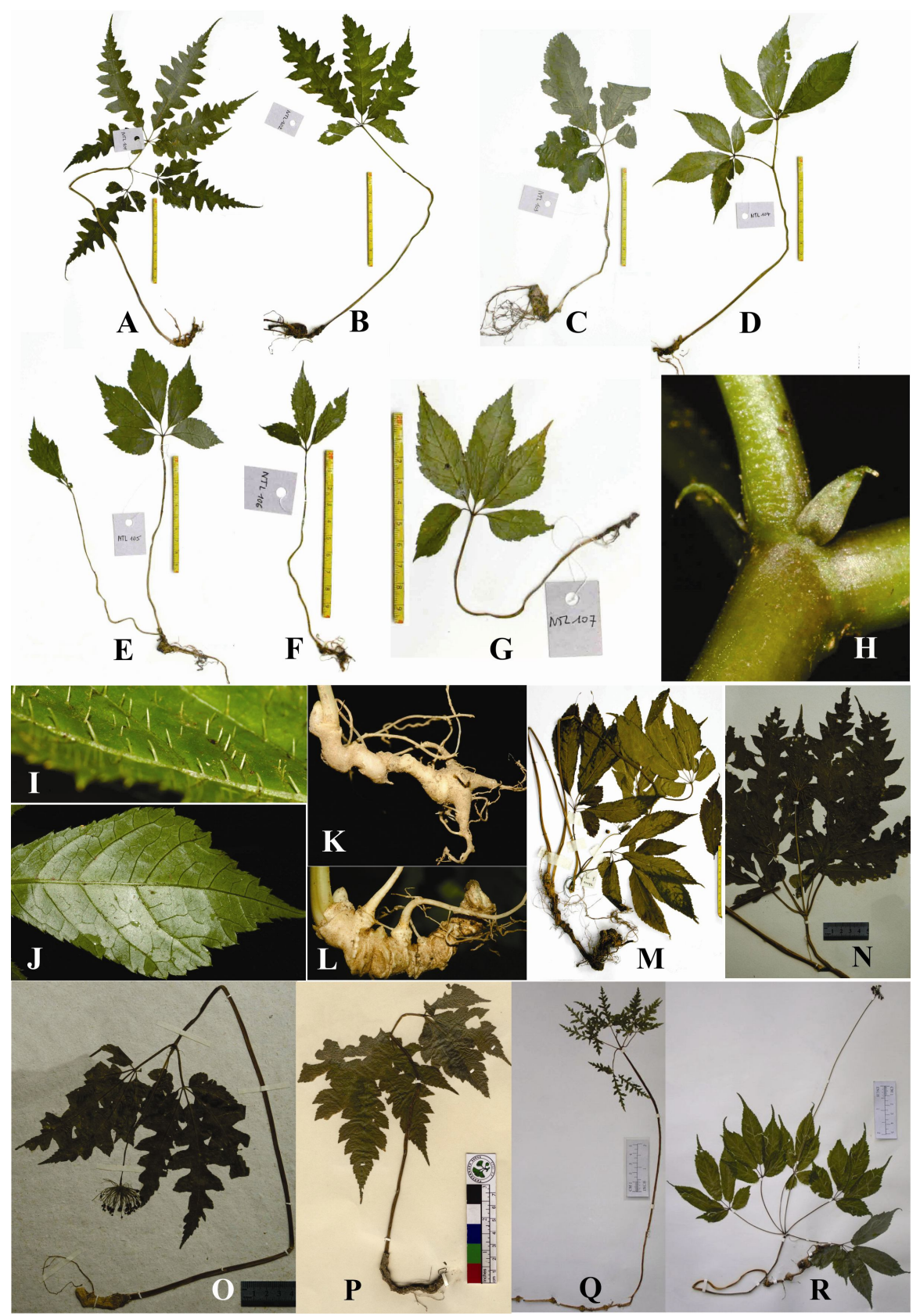

Figure 1. A- NTL 101; B- NTL 102; C- NTL 103; D- NTL 104; E- NTL 105; F- NTL 106; G- NTL 107; H- Stipules; I- Scattered setulose hairs on veins on adaxial leaf surface; J- Abaxial leaf surface; K- Rhizome of NTL 106; L- Rhizome of NTL 101; M- Panax stipuleanatus H.T.Tsai \& K.M.Feng, Vietnam: Lai Chau, Tam Duong, Khun Ha, P 11172 (VNMN!, HNU!); N- Panax stipuleanatus, Vietnam: Lao Cai, Sa Pa, Sino-Viet. Exp. 344 (KUN 0560456!); O- Panax stipuleanatus, China, 23014 (KUN 0560447!); P- Panax stipuleanatus-Type: China: Yunnan, Feng 13694 (Iso- KUN 0448506!); Q- Panax bipinnatifidus Seem., forma 2-pinnatifid. China: Xizang (After J. Wen, 1539155!); R- Panax bipinnatifidus Seem., forma undivided. China: Yunnan (After J. Wen, 1410528 !). 


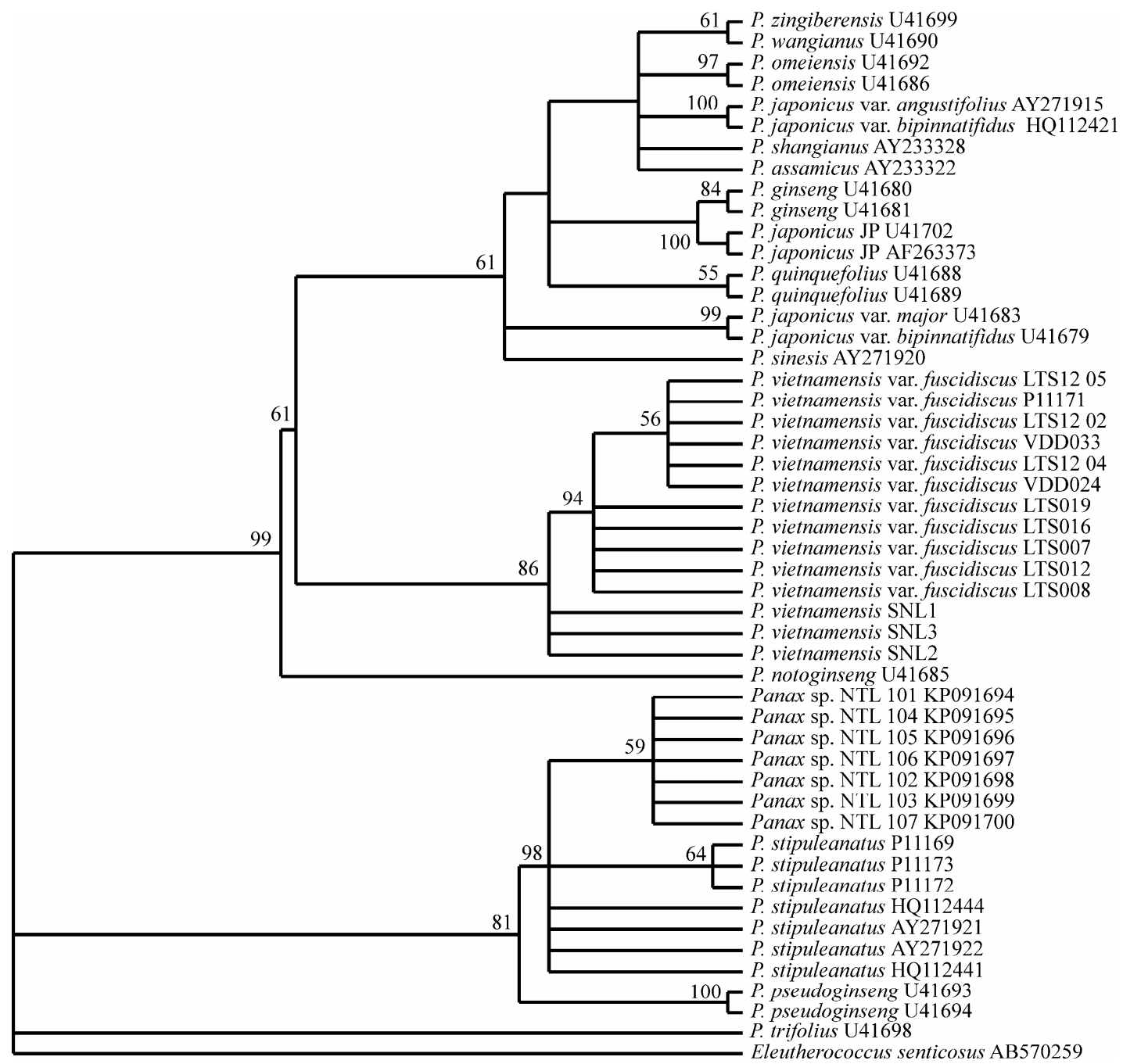

Figure 2. The molecular relationship of Panax sp. collected from Phu Xai Lai Leng Mountain, Western Nghe An Province with other Panax spp. based on MP analysis. Eleutherococcus senticosus AB570259 is the outgroup taxon.

This group is close to PXLL-1 but differs only by leaflets undivided, not lobed nor divided.

Herb, perennial, 0.17-0.25 $\mathrm{m}$ tall (without inflorescence/infructescence). Rootstock moniliform-mounded, usually horizontal, resembling that of species of Zingiber. All plant parts glabrous except for scattered setulose hairs on veins of adaxial leaf surface, very rare on abaxial leaf surface; trichomes $1.5-2 \mathrm{~mm}$ long. Plant young, having two leaves opposite or one leaf on top of stem; petiole base with stipules deltoid-cuspidate or stipule-like appendages.
Leaves palmately compound; petiole ca. 3.5-5 $\mathrm{cm}$ long; leaflets (3-)5(-7), oblanceolate in outline, acute at base, cuspidate $(1.5-2 \mathrm{~cm})$, rarely acuminate at apex, membranous, undivided, margin serrulate. Median leaflet biggest, up to $6-11 \times 1.5-3.5 \mathrm{~cm}$ including petiolule with leaf blade 2.7-2.9 $\times$ as long as wide and petiolules $0.2-0.5 \mathrm{~cm}$ long; lateral leaflets smaller, two lowest leaflets smallest, asymmetric, blades entire, ca. $1.5 \times 0.9 \mathrm{~cm}$, serrulate at top. Inflorescence and infructescence, flowers and fruits unknown. Rare. 
Morphological and molecular characteristics of Panax sp.

The specimens differ from Panax stipuleanatus by the smaller vegetative parts, petiole base with stipules or stipule-like appendages and leaflets not bipinnatifid.

The specimens differ from Panax bipinnatifidus in the undivided leaflets not lobed nor divided as in Panax bipinnatifidus and by the adaxially sparsely setose leaflets and the base of petiole with stipules or stipule-like appendages.

\section{Molecular relationship with other species}

The length of the Panax sp. ITS-rDNA sequence for alignment with an outgroup taxon was $587 \mathrm{bp}$ and all of them are identical. MP analysis of this alignment indicated that among 588 characters, 69 were parsimony informative. In the consensus MP tree (fig. 1), the Panax sp. is clustered with the clade of $P$. stipuleanatus and $P$. pseudoginseng with a moderate bootstrap support $(81 \%)$ and they have sister relationship with P. stipuleanatus (KJ418187, KJ418197, KJ418198) from Tam Duong, Lai Chau with strong bootstrap support (98\%) (fig. 2).

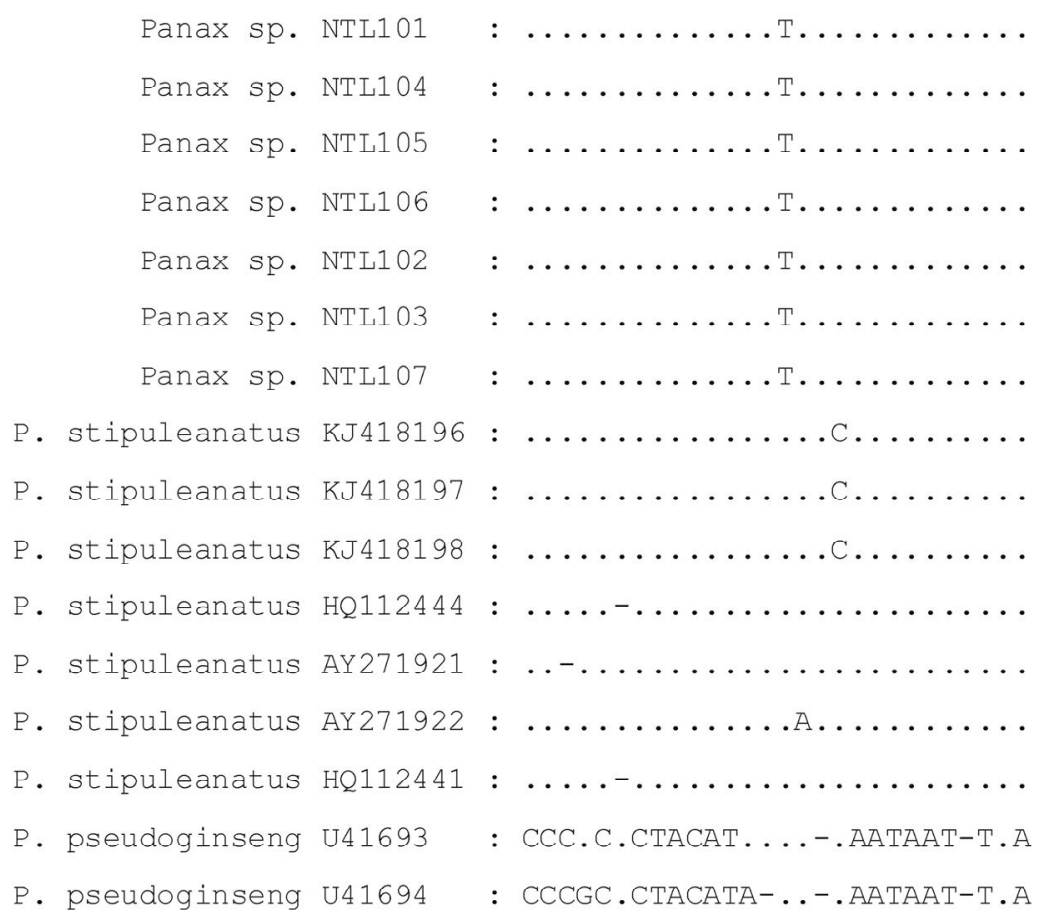

Figure 3. The nucleotide variation in the ITS-rDNA region of the $P$. stipuleanatus clade

\section{Sequence variation}

The ITS-rDNA sequence of Panax sp. was $587 \mathrm{bp}$, the same as for $P$. stipuleanatus from Tam Duong, Lai Chau (KJ418187, KJ418197, KJ418198) and P. stipuleanatus AY271922; longer than that of $P$. stipuleanatus (HQ112444, AY271921, HQ112441) and P. pseudoginseng (U41693, U41694). The ITS-rDNA sequences of Panax sp. differed from sister clade of $P$. stipuleanatus (KJ418187, KJ418197, KJ418198) by 2 nucleotides (fig. 3).
Although the specimens of Panax sp. collected from Phu Xai Lai Leng mountain, western Nghe An Province were divided to two groups, PXLL-1 and PXLL-2 based on the morphology of leaflets, the ITS-rDNA sequences of all these specimens were identical. Therefore they should be regarded as the same infraspecific taxon.

\section{CONCLUSION}

According to the morphology of leaflets and molecular data, the Panax sp. collected from 
Phu Xai Lai Leng mountain, western Nghe An Province could be considered as a new variety of Panax. Additional collection including inflorescence, infructescence, flowers and ripe fruits of the Panax sp. from Phu Xai Lai Leng is needed to determine its taxonomic status.

\section{REFERENCES}

1. Ha Thi Dung, Grushvitsky I. V., 1985. A new species of the genus Panax (Araliaceae) from Vietnam. Bot. J. (Leningrad): 519-522.

2. Phạm Hoàng Hộ, 1993. An Illustrated Flora of Vietnam II-2: 640-641 Montréal (in Vietnamese).

3. Phạm Hoàng Hộ, 2000. An Illustrated Flora of Vietnam II: 515-516. Youth Publ. House, Ho Chi Minh city (in Vietnameme).

4. Phan Ke Long, Vu Dinh Duy, Phan Ke Loc, Nguyen Giang Son, Nguyen Thi Phuong Trang, Le Thi Mai Linh, Le Thanh Son, 2014. Phylogenetic relationships of the Panax samples collected in Lai Chau Province based on MATK and ITS-rDNA sequences. J. Biotechnol. (Vietnam), 12(2): 327-337 (in Vietnamese).

5. Mabberley D. J., 1987. The Plant-Book. Second ed. Cambridge University Press.

6. Mabberley D. J., 2008. Mabberley's PlantBook. Third ed. Cambridge.

7. Swofford, D. L., 1998. PAUP* Phylogenetic analysis using parsimony. Version 4. Sinauer, Sunderland, MA. 128 pp.

8. The Plant List, 2014. Collaboration between the Royal Botanic Gardens, Kew and Missouri Botanical Garden.

9. Thompson J. D., Gibson T. J., Plewniak F., Jeanmougin F., Higgins D. G., 1997. The ClustalX windows interface: flexible strategies for multiple sequence alignment aided by quality analysis tools. Nucleic Acids Research, 24: 4876-4882.

10. Xiang Q. B., Lowry II P. P., 2007. Panax: 489-491. In Z.Y. Wu, P.H. Raven \& D.Y. Dong (eds.). Flora of China 13. Sci. Press (Beijing) \& Missouri Botanical Garden Press (St. Louis).

\title{
ĐẠC ĐIỂM HİNH THÁI VÀ PHÂN TỦ CỦA Panax sp. (Araliaceae) THU Ở NÚI PHU XAI LAI LENG, TỈNH NGHỆ AN, VIẸT NAM
}

\author{
Phan Kế Long ${ }^{1 *}$, Trần Thị Việt Thanh ${ }^{1}$, Nguyễn Thiên Tạo ${ }^{1}$, \\ Phan Kế Lộc ${ }^{2}$, Nguyễn Tư Lệnh ${ }^{3}$, Nguyễn Tiến Lâm ${ }^{3}$, Đặng Xuân Minh ${ }^{3}$ \\ ${ }^{1}$ Bảo tàng Thiên nhiên Việt Nam, Viện Hàn lâm KH \& CN Việt Nam \\ ${ }^{2}$ Trường Đại học Khoa học Tự nhiên, ĐHQG Hà Nội \\ ${ }^{3}$ Sở Nông nghiệp và Phát triển Nông thôn, Nghệ An
}

\section{TÓM TẮT}

Bài báo trình bày kết quả phân tích 7 mẫu không mang cơ quan sinh sản và còn non của Sâm Panax sp. được thu thập trên núi đá silicát Phu Xai Lai Leng, núi cao nhất Bắc Trung bộ Việt Nam, ở vị trí 19²13' vĩ Bắc, $104^{\circ} 12^{\prime}$ kinh Đông, độ cao $1600 \mathrm{~m}$ so với mặt nước biển. Về hình thái, chúng rất gần với loài $P$. stipuleanatus và $P$. bipinnatifidus. Tuy nhiên, chúng có lá kèm và lá chét không xẻ lông chim 2 lần. Trình tự vùng gen ITS-DNA của Panax sp. ở Phu Xai Lai Leng giống hệt nhau, và có mối quan hệ gần gũi với P. stipuleanatus thu ở Tam Đường, Lai Châu với bootstrap lên đến $98 \%$. Tuy nhiên, giữa chúng có sự sai khác ở 2 nucleotide. Việc thu thập mẫu có đầy đủ cụm hoa, cụm quả, hoa và quả chín của sâm Panax sp. ở Phu Xai Lai Leng là ưu tiên hàng đầu để xác định vị trí phân loại của loài.

Tù khóa: Panax, ITS-rDNA, hình thái, núi đá xilicát, Phu Xai Lai Leng.

Ngày nhận bài: 5-7-2014 